Diuretics have revolutionised the management of patients with heart failure, and they are one of the most useful treatments for hypertension. They should be used, however, only where there is a good clinical indication and adequate facilities exist for clinical and biochemical follow-up. Potassium supplements or a potassium-conserving diuretic should be given to all patients receiving digitalis and diuretics concurrently, and the combination can probably be justified in most other elderly patients on diuretics.

\footnotetext{
1 Wadsworth, M E J, Butterfield, W J H, and Blaney, R, Health and Sickness. The Choice of Treatment. London, Tavistock Publications, 1971.

2 Bytheway, B, Fournal of the Royal College of General Practitioners, 1976, 26, suppl 1, 40 .

${ }^{3}$ Shaw, S M, and Opit, L J, British Medical Fournal, 1976, 1, 505.

4 Law, R, and Chalmers, C, British Medical fournal, 1976, 1, 565.

'Skegg, D G G, Doll, R, and Perry, J, British Medical fournal, 1977, 1, 1561 .

'Agate, J, The Practice of Geriatrics, 2nd edn. London, Heinemann, 1970.

7 Burr, M L, et al, Age and Ageing, 1977, 6, 38.

* Amery, A, et al, Gerontology, 1977, 23, 426.

${ }^{9}$ Jackson, G, et al, Lancet, 1976, 2, 1317.

10 Caird, F I, Prescribers' fournal, 1977, 17, 52.

11 Davies, D L, and Wilson, G M, Drugs, 1975, 9, 178.

12. MacLeod, C C, Judge, T G, and Caird, F I, Age and Ageing, 1975, 4, 49.

${ }^{13}$ Farquharson-Roberts, M A, Giddings, A E B, and Nunn, A J, British Medical fournal, 1975, 3, 206.

${ }^{14}$ Brook, R H, et al, New England fournal of Medicine, 1971, 285, 1509.

15 Amery, A, et al, Lancet, 1978, 1, 681.
}

\section{Stab wounds of the spinal cord}

Outside South Africa, stab wounds of the spinal cord are uncommon. In California, ${ }^{1}$ for example, there were only 19 cases in over 50000 admissions with traumatic injuries over 33 years, and in over 4000 patients with injury to the spinal cord seen at Stoke Mandeville Hospital, England, over 27 years only four had a stab wound. ${ }^{2}$ In contrast, in a recent $12-$ month period 4280 patients with stab wounds were treated in the Groote Schuur Hospital in Cape Town, and 12 of these had spinal cord damage, while in the Spinal Cord Injury Centre in that city 450 of the 1600 patients admitted in 13 years had sustained a stab wound of the spinal cord. ${ }^{3}$ The reasons for stabbing included robbery, gang warfare, and jealousy. The weapon was usually a knife, but might be an axe, a screwdriver, or a sharpened bicycle spoke; and $65^{\circ} \%$ of victims had a single wound.

In this type of injury the assailant usually attacks his victim from behind, ${ }^{4}$ striking the upper dorsal region. The anatomy of the vertebral column is such that the blade tends to enter the gutter formed by the spinous process in the midline and the transverse processes laterally, often being deviated laterally by the dorsal projection of the transverse processes. ${ }^{3} \mathrm{~A}$ contrecoup spinal cord lesion may occur. ${ }^{5}$ Sometimes fragments of a lamina are driven into the spinal canal, and a thin weapon may enter an intervertebral foramen. ${ }^{6}$ There are parallels with what may occur in the estocada in bull-fighting, when the matador uses a sword (estoque) to kill the bull by a thrust between the scapulae to reach the heart and aorta; if he is unsuccessful a coup de grace is required, delivered by piercing the spinomedullary region through the occipitoatlanto interval with a dagger.

Distinct clinical neurological patterns result from stab injuries to the cord. Between $70 \%$ and $80 \%$ of patients have an incomplete lesion ${ }^{3}$ - usually some form of Brown-Séquard syndrome, ${ }^{7-10}$ as was shown in $69 \%$ of those with partial lesions in the largest reported series. ${ }^{3}$ Other authors confirm this frequency. ${ }^{1411-17}$ The syndrome usually consists of ipsilateral motor and proprioceptive loss and marked hyperaesthesia to pin prick, with contralateral loss of pain and temperature sensation.

Neurological damage from stab wounds of the spine may be delayed, ${ }^{11} 1+17-19$ the interval varying from two to as long as 36 years. In all such cases reported a broken piece of knife blade had been left in situ in the spinal canal. Sometimes no radiograph had been taken initially, or the picture was not good enough to show the piece of knife blade; sometimes no action had been taken to operate and remove the portion of knife. In such cases the patient may give a history of a second relatively minor head or closed spinal injury which appeared to trigger off spinal neurological abnormalities. Other, rarer causes of delayed or of increasing neurological signs are spinal abscess (epidural, subdural, or intramedullary); granulomatous tissue formation; or iron encrustation around a retained portion of the knife.

Myelography is indicated only if there has been progressive neurological deterioration, most often in the early stages after injury due to an abscess. Lumbar puncture is of no diagnostic or prognostic value and is required only if meningitis is suspected. In most patients who have had a stab injury of the spine there is no call for major surgery, ${ }^{35}$ though many patients have associated injuries which may require special treatment. $^{20}$ The local wound needs excision and careful closure in layers, and prophylactic antibiotics and antitetanus treatment should be given. ${ }^{21}$ Patients with anything more than minor neurological abnormalities should be admitted as soon as possible to a specialist spinal unit. Bed rest is not necessary (from the neurological point of view) since the spine is usually stable. Laminectomy will be needed only if there is a retained portion of the weapon; if indriven fragments of bone are compressing the spinal neural elements (for such fragments must be removed under direct vision ${ }^{3}$ ); or if a cerebrospinal fluid leak persists for more than three or four days. ${ }^{35}$ Appropriate treatment may also be needed for a spinal abscess; even intramedullary lesions may have an excellent prognosis. ${ }^{22}$ Any removal of intramedullary extension of granulation tissue may aggravate neurological symptoms and signs, ${ }^{11} 1417$ and this must be done with extreme care, preferably under a dissecting microscope and with the aid of bipolar coagulation diathermy.

Stab wounds affecting the cauda equina roots present a special therapeutic problem, and exploratory laminectomy after myelography is recommended for such patients. ${ }^{21}$ Attempts have been made to suture lacerated cauda equina roots, but they do not have an adequate sheath to make suturing reliable. ${ }^{15}$ Regeneration of anterior spinal roots may occur, but this is much less likely with posterior roots. Nevertheless, even after a delay of many years operations on adherent and partially severed cauda equina roots may sometimes result in useful functional recovery. ${ }^{23}$

While the prognosis is poor in those patients who have a complete spinal cord lesion lasting over 24 hours, in those with partial lesions-and especially with a Brown-Séquard type of syndrome-good functional neurological recovery frequently occurs. ${ }^{1346}$ In the largest reported series, $66 \%$ of 450 patients with stab wounds could eventually walk without help or with minimal aid-a walking stick or a below knee-calliper. Recovery was fair in $17 \%$, and $16(3.6 \%)$ died. There were nine early deaths from meningitis or pulmonary embolism; wound sepsis was rare. In another large series ${ }^{6}$ of 217 patients with in- 
complete neurological lesions over half returned to their former occupation, usually within six months of the injury.

\footnotetext{
${ }^{1}$ Rosenberg, A W, Bulletin of the Los Angeles Neurological Society, 1957, 22, 79.

2 Guttmann, L, Spinal Cord Injuries, 2nd edn, chap 15, p 188. Oxford, Blackwell, 1976.

3 Peacock, W J, Shrosbee, R D, and Key, A G, South African Medical fournal, 1977, 51, 961.

${ }^{4}$ Nagoulitch, I, Borne, G, and Belval, J, Lyon Chirurgical, 1968, 64, 424.

5 Lipschitz, R, and Block, J, Lancet, 1962, 2, 169.

${ }^{6}$ Lipschitz, R, in Handbook of Clinical Neurology, vol 25, eds P J Vinken and G W Bruyn, chap 10, p 197. Amsterdam, North Holland Publ Co, 1976.

${ }^{7}$ Brown-Séquard, C E, Recherches Expérimentales sur la Physiologie de la Moelle Epinière. Thesis, Paris, 1846.

${ }^{8}$ Brown-Séquard, C E, Comptes Rendus des Séances de la Socièté de Biologie et $d e$ ses Filiales, 1849, 1, 192.

${ }^{9}$ Brown-Séquard, C E, Experimental and Clinical Researches on the Physiology and Pathology of the Spinal Cord. Richmond, Colin and Nowlan, 1855

${ }^{10}$ Brown-Séquard, C E, Lectures on the Diagnosis and Treatment of the Principal Forms of Paralysis of the Lower Extremities. Philadelphia, Collins, 1861 .

11 Adornato, D C, jun and Collis, J S, International Surgery, 1972, 57, 147.

12 Binnert, D, et al, fournal de Médecine de Lyon, 1971, 52, 685.

13 Guillaine, G, and Corre, L, Bulletin de l'Académie de Médecine, 1950, 134, 147.

14 Guillain, G, and Garcin, R, Annales de Médecine, 1931, 29, 361.

15 Le Blanc, H J, Gray, L W, and Kline, D G, fournal of Neurosurgery, 1969, 31, 683 .

16 Rand, C W, and Patterson, G H, Surgery, Gynecology and Obstetrics, $1929,48,652$.

17 St John, J R, and Rand, C W, Bulletin of the Los Angeles Neurological Society, 1953, 18, 1.

18 Wolf, S M, Fournal of Neurosurgery, 1973, 38, 221.

19 Antonelli, G, Policlinico (sez med), 1932, 39, 467.

20 Jones, W A, Fournal of the American Medical Association, 1943, 121, 1004.

${ }^{21}$ Harris, P, in Hamilton Bailey's Emergency Surgery, 10th edn, ed H A F Dudley, p 161 and 169. Bristol, John Wright, 1977.

22 Wright, R L, Fournal of Neurosurgery, 1965, 23, 208.

${ }^{23}$ Landau, B, and Ransohoff, J, fournal of Neurosurgery, 1968, 28, 257.
}

\section{Discord at Dulwich}

"At 4 pm, while these discussions [on the Dulwich Hospital theatre dispute] were proceeding, there was a disturbance in the main theatre suite between nursing and medical staff on one hand and theatre orderlies on the other. A very tense situation appeared to have developed involving use of theatre port-holes. This was emphasised when two surgeons informed sector administration that, in their view, it was unsafe to operate in the emotional atmosphere then prevailing in the theatres. The indications were that nurses in the theatres were not prepared to work with the theatre orderlies and vice versa. The two groups were accordingly separated and it appeared to local management that, given the hostile atmosphere, there was a need to effect a temporary closure of the main theatre suite."

Who could believe that such a scene was possible in an NHS operating theatre? Yet it is described in the guardedly worded report $^{1}$ on recent events in Dulwich Hospital's operating theatre, prepared by a local joint staff management panel. Some may be tempted to dismiss the trouble at Dulwich as untypical of the hospital service and a consequence of personality clashes. The inquiry's findings are, however, an unhappy confirmation of developments in the NHS about which we warned at the end of last year. ${ }^{2}$
The culminating row that stopped the operating theatre erupted over the threatened disciplining of a theatre porter who had persisted in parking his bicycle in the operating theatre changing room used by orderlies and students. This precipitated a demand by representatives of the ancillary staff for the removal of the nursing officer in charge of the operating $\stackrel{\mathbb{D}}{\circ}$ suite. The report makes clear, however, that relations between $\subseteq$ doctors and the nurses on the one hand and theatre orderlies $\overrightarrow{\vec{F}}$ on the other had been deteriorating for a long time, well $\frac{\text { }}{0}$ before the present nursing staff arrived. Furthermore, indus- $\frac{c}{\sigma}$ trial relations in the hospital as a whole had been unhappy, $\bar{\sigma}$ with industrial action threatened or taken "from time to time." But tensions reached such a pitch after the bicycle incident that, while discussions to resolve the problem were proceeding, the disturbance in the main theatre occurred.

Anyone with experience of operating theatre work knows $\overrightarrow{\vec{\omega}}$ that it is physically and mentally demanding. Even the relative $\frac{D}{O}$ calm of a routine hernia operation can be broken by an un- 3 expected emergency, when only disciplined action may stand $\overrightarrow{-}$ between the patient and disaster. If supporting staff cannot $\frac{\sigma}{7}$ be relied upon to play their essential part then patients entering $\stackrel{N}{\circ}$ the operating theatre are facing unreasonable hazards. Anyone $\vec{\circ}$ in a theatre who is not prepared to act responsibly should not $\stackrel{\oplus}{\omega}$ be there. This may mean sacking staff. But one of the important 웅 -and literally dangerous in this context-consequences of $\mathbb{6}$ recent legislation ${ }^{3}$ is to make management reluctant to dismiss $D$ even persistent trouble makers. This has emboldened unions and their members to behave on occasions as though running $\vec{\varphi}$ the organisation was their responsibility. Paradoxically, while resisting dismissal or transfer themselves, ancillary workers o are not averse to demanding the removal of more senior staff whom they dislike, as happened at Dulwich. While they may gain in the short term from such anarchic behaviour, in the long run everyone suffers. In the case of Dulwich the waiting $\stackrel{\mathbb{Q}}{\varrho}$ list for gynaecological operations apparently doubled during $\overrightarrow{\overrightarrow{0}}$ the six weeks of the dispute.

The report clears the theatre nursing officer of any blame, judging that there was not even prima facie evidence to justify the ancillary staff's complaints. It also makes some sensible if obvious recommendations, calling for a review of theatre rules and practice, more training and a $\frac{\sigma}{3}$ better career pattern for ancillary staff, a clear chain of $\stackrel{3}{.}$ accountability in the theatre, greater understanding by staff of everyone's duties, and training for key administrators in industrial relations. The unhappy events in Dulwich, however, 은 are a warning to all NHS staff. They should heed it: adminis- $\widetilde{N}$ trators when tempted to appease militant staff, union leaders $\frac{D}{O}$ when tempted to support unquestioningly local militants, and doctors and nurses when tempted to deliver authoritarian $\tilde{\mathcal{O}}$ commands to staff. Otherwise all the money in the world will $\mathrm{\omega}$ not make the NHS a safe place for patients to be ill in.

${ }^{1}$ Report of a Committee Appointed to Inquire into a Situation within Main Operating Theatre Suite at Dulwich Hospital. London, King's ? Health District (Teaching), 1978.

${ }^{2}$ British Medical fournal, 1977, 2, 1619.

${ }^{3}$ Employment Protection Act 1975. London, HMSO, 1975.

\section{Correction}

We regret that in the leading article "To sign or not to sign ?" (11 March, p 598) we quoted the second reference wrongly. It should have $\frac{\bar{Q}}{\partial}$ been De Bakey, L, The Scientific fournal, St Louis, Mosby, 1976. 